Available online at website :

http://e-journal.adpgmiindonesia.com/index.php/jmie

JMIE: Journal of Madrasah Ibtidaiyah Education, 4(1), 2020, 22-38

\title{
ANALISIS DESKRIPTIF RENDAHNYA HASIL BELAJAR SEJARAH KELAS V SDN PANANCANGAN 4 KOTA SERANG
}

\author{
Khaeroni ${ }^{1)}$, Asep Saefurohman ${ }^{2)}$, Nurmala Sari $^{3)}$ \\ Universitas Islam Negeri (UIN) Sultan Maulana Hasanuddin Banten1),2) \\ Sekolah Dasar (SD) Assa'adah Global Islamic School (AGIS) ${ }^{3)}$ \\ Email: khaeroni@uinbanten.ac.id1), asep.saefurohman@uinbanten.ac.id,2) \\ mallaikhata25@gmail.com³)
}

Naskah diterima : 4 Oktober 2019, direvisi : 7 Maret 2020, disetujui : 1 April 2020

\begin{abstract}
The purpose of this study is to identify the factors causing the low learning outcomes of Historical Material at 5th class SDN Panancangan 4 Serang. This research uses the descriptive qualitative method. The subjects acting as data sources for this study were teachers, students, and parents or guardians of students who experienced problems. Data from each subject was collected through observation, interviews, and documentation of student learning outcomes. Students who experience difficulties in learning history are $92 \%$ of students in 5th class. The type of difficulties is lack of understanding of students in historical material, unable to ask a question, hard to remember particular names, a period of an event and its legacy, and uncorrected learning strategy applied. The result shows that the factors that caused the low learning outcomes in historical material were classified into two factors. First, internal factors such as psychological, motivation, and learning concentration. Second, external factors such as parents' attention in assisting learning outside of school which are still minimum, teaching strategy applied, and the limited media or learning resources. One effort that needs to be applied to improve the results of learning history is by doing apperception before learning activities. Apperception contains activities conveying learning objectives, the benefits of learning historical material, learning activity scenarios, and preparing students physically and psychologically to be ready to learn. Also, the teacher can choose learning activities that suitable with the learning styles of students, enrich learning resources other than books, and close learning activities with messages implied from historical events being studied.
\end{abstract}

Keywords: Low student learning outcomes, Material history, Social Study

Pengutipan: . Khaeroni, dkk. (2020). Analisis Deskriptif Rendahnya Hasil Belajar Sejarah Kelas V SDN Panancangan 4 Kota Serang. JMIE: Journal of Madrasah Ibtidaiyah Education,4(1), 22-38. jmie.v4i1.122. 


\section{PENDAHULUAN}

Kurniawan, Wiharna, \& Permana menyatakan bahwa salah satu tolok ukur keberhasilan belajar adalah hasil belajar. Oleh karena itu, dapat dikatakan bahwa hasil belajar memegang peran strategis dalam kegiatan belajar (Kurniawan, Wiharna, \& Permana, 2017). Hasil belajar adalah ukuran yang menyatakan kemampuan yang dicapai oleh seorang siswa atau pembelajar setelah mengalami kegiatan belajar (Susanto, 2013, hal. 12-13). Sejalan dengan Susanto, Tanjung menyebutkan bentuk-bentuk kemampuan yang dimaksud adalah keterampilan dan perilaku pembelajar (Tanjung, 2015). Hasil belajar menunjukkan adanya perubahan siswa baik dalam hal keterampilan maupun perilakuknya. Ada atau tidaknya perubahan pada aspek-aspek tersebut menunjukkan seberapa tinggi hasil belajar yang diperoleh. Oleh karena itu, sebagian besar guru menjadikan hasil belajar sebagai salah satu komponen evaluasi untuk memutuskan apakah seorang siswa dinyatakan berhasil mencapai tujuan pembelajaran atau tidak. Evaluasi juga dilakukan untuk menemukan apa saja kelemahan atau kekurangan yang ada dalam kegiatan belajar.

Tidak dapat dipungkiri bahwa setiap siswa memilik hak untuk mencapai prestasi akademik yang baik. Namun, kenyataan menunjukan bahwa siswa memiliki kelebihan dan kekurangan baik secara intelektual, atau fisik. Demikian juga dengan kebiasaan, latar belakang keluarga, dan gaya belajar yang berbeda-beda. Pengukuran hasil belajar siswa sebagai kemampuan yang dihasilkan melalui proses belajar menunjukkan kualitas atau derajat yang beragam. Sebagian siswa mungkin menunjukkan hasil belajar yang tinggi dengan mudah, tetapi sebagiannya lagi tidak demikian. Ada beberapa di antara mereka yang mendapatkan hasil belajar yang kurang baik karena tidak bisa mengikuti kegiatan belajar dengan mudah. Bahkan sebagian di antaranya mengalami hambatan dalam belajar. Hambatan ini menjadi salah satu faktor rendahnya hasil belajar siswa. Faktor lain adalah kesulitan belajar. Sebagai hasilnya, pengukuran hasil belajarnya menunjukkan angka atau derajat yang rendah.

Fenomena rendahnya hasil belajar, terjadi pada pembelajaran sejarah di Kelas V SDN Penancangan 4 Kota Serang Provinsi Banten. Berdasarkan hasil observasi diperoleh informasi bahwa lebih dari 30 orang siswa dari 37 siswa atau lebih dari 81\% siswa di kelas tersebut mendapatkan hasil belajar yang rendah. Siswa dikatakan memiliki hasil belajar yang rendah apabila hasil belajar mereka berada di bawah (atau kurang dari) Kriteria Ketuntasan Minimal (KKM) yang telah ditetapkan untuk materi tersebut.

Rendahnya hasil belajar dapat diakibatkan oleh adanya kesulitan belajar yang dialami siswa. Kesulitan belajar adalah hambatan atau penghalang yang dihadapi ketika siswa belajar. Baharudin \& Wahyuni menyebutkan ada beberapa faktor yang menentukan bagaimana siswa belajar, yakni faktor internal dan faktor eksternal (Baharudin \& Wahyuni, 2008, hal. 19-28). Faktor internal adalah faktor yang berasal dari dalam diri siswa baik dari sisi fisiologis seperti kesehatan dan keadaan fisik, maupun psikologis seperti kecerdasan, motif, motivasi, minat, 
daya nalar, bakat, dan keadaan mental. Sementara faktor eksternal adalah faktor yang berasal dari luar diri siswa. Secara umum, terdapat dua jenis faktor eksternal, yakni faktor lingkungan dan faktor instrumental atau perangkat. Terdapat dua jenis faktor yang lingkungan, yakni lingkungan sosial seperti sekolah, masyarakat, dan keluarga, dan lingkungan fisik seperti suhu, kelembapan, dan cuaca. Adapun faktor instrumental adalah faktor yang keberadaan dan penggunaannya dibuat sesuai dengan tujuan belajar yang diharapkan.

Senada dengan pendapat di atas, Slameto menyatakan bahwa faktor internal meliputi tiga hal. Pertama jasmaniah, yakni keadaan di mana siswa dalam kondisi siswa sehat dan jauh dari penyakit. Siswa yang terganggu secara jasmaniah seperti sakit atau memiliki penyakit akan memengaruhi hasil belajar mereka. Kedua psikologis, yakni kemampuan dalam diri siswa seperti perhatian, minat, bakat, motif, kematangan dan kedewasaan. Ketiga motivasi, yaitu situasi dalam diri siswa merasa semangat dalam belajar, menikmati, dan tidak bosan untuk belajar. (Slameto, 2015, hal. 54). Selain itu, faktor eksternal juga dikategorikan menjadi tiga hal, yaitu: keluarga, sekolah, dan masyarakat. Selain ketiga faktor tersebut terdapat faktor lain yaitu sindrom psikologi berupa ketidakmampuan belajar (Syah, 2013, hal. 185-186). Kedua faktor tersebut (internal dan eksternal) dapat menjadi penghambat ataupun pendukung belajar siswa. Faktorfaktor di atas juga menjadi penentu bagaimana siswa mampu mencapai prestasinya khususnya dalam akademik (Khaeroni \& Nopriyani, 2018). Fokus dari penelitian ini adalah pada faktorfaktor yang memengaruhi hasil belajar.

Sari \& Zulfa menyatakan bahwa intelegensi merupakan salah satu faktor yang memengaruhi hasil belajar. Karena intelegensi atau kecerdasan merupakan daya serap pikir anak yang sangat cepat yang dimiliki seseorang. Siswa dengan tingkat kecerdasan yang tinggi akan mudah menyerap informasi yang mereka terima. Sebaliknya, tidak demikian bagi siswa dengan tingkat kecerdasan yang rendah. Mereka akan mengalami kesulitan untuk menyerap informasi yang mereka terima (Sari \& Zulfa, 2019). Akan tetapi, karena keterbatasan instrumen pengukuran, maka penelitian ini tidak memfokuskan faktor penyebab pada tingkat intelektualitas siswa.

Ibu Rohayati selaku Wali Kelas V menyebutkan beberapa faktor yang mengakibatkan siswa memiliki hasil belajar yang rendah pada materi sejarah, yaitu:
a. Lingkungan belajar yang kurang kondusif
b. Kurangnya interaksi antara siswa dan guru
c. Banyak siswa yang kurang memahami pembelajaran sejarah
d. Siswa kurang memperhatikan guru
e. Kurangnya dorongan dari diri siswa dalam belajar
f. Kurangnya pemanfaatan media pembelajaran oleh guru
g. Kurangnya peran orang tua dalam mendampingi siswa belajar di luar kelas. 
Bila tidak segera ditangani, rendahnya hasil belajar sejarah pada siswa akan memicu kemunculan berbagai masalah-masalah lain yang bahkan bisa lebih parah. Salah satu masalah utama yang dihadapi adalah ketidakpahaman generasi muda terhadap masa lalu bangsa serta nilai-nilai historis yang terkandung di dalamanya. Upaya untuk memperbaiki rendahnya hasil belajar siswa secara umum dapat dilihat dari beberapa aspek, terutama aspek-aspek yang memengaruhi proses belajar (Tanjung, 2015). Berdasarkan uraian di atas maka perlu dideskripsikan faktor-faktor yang menyebabkan rendahnya hasil belajar siswa Kelas V SDN Panancangan 4 Kota Serang khususnya pada pelajaran sejarah. Adapun secara garis besar, tujuan penelitian ini adalah untuk mengetahui apa saja faktor yang menyebabkan rendahnya hasil belajar siswa pada mata pelajaran sejarah, untuk mengetahui apa saja upaya yang perlu dilakukan untuk mengatasi faktor-faktor tersebut dalam upaya meningkatkan hasil belajar siswa pada mata pelajaran sejarah.

\section{METODE PENELITIAN}

Metode penelitian yang digunakan dalam penelitian adalah metode kualitatif. Penelitian kualitatif dapat diartikan sebagai penelitian ilmu sosial dengan cara mengumpulkan data baik berupa kata-kata, kalimat, ataupun perbuatan manusia. Penelitian ini dilakukan di SDN Penancangan 4 Kota Serang Provinsi Banten. Tepatnya di Jl. Raya Bangdes RT 01 RW 11 Kp. Turus Kelurahan Panancangan Kec. Cipocok Jaya Kota Serang Provinsi Banten 42124. Penelitian ini menggunakan teknik purposive sampling untuk memilih anggota sampel. Kriteria pemilihan anggota sampel adalah 1) Siswa yang memiliki hasil belajar di bawah nilai KKM, dan 2) Guru yang mengajarkan mata pelajaran sejarah. Data penelitian kemudian dikumpulkan dari sampel dengan menggunakan teknik sebagai berikut: 1) observasi; 2) wawancara; dan 3) dokumentasi. Sementara itu uji keabsahan data dilakukan dengan cara mengadakan pengisian angket/kuesioner.

Sesuai dengan jenis data yang dikumpulkan, maka penelitian ini menggunakan teknik analisis data kualitatif. Langkah-langkah analisis data kualitatif yang dilakukan terhadap data yang diperoleh adalah 1) mengelompokkan data yang telah diperoleh; 2) memilahnya menjadi satuan agar dapat di olah menjadi laporan penelitian; 3) menyintesiskannya setelah mengetahui pola yang digunakan; dan 4) mengambil kesimpulan secara objektif berdasarkan temuan penelitian (Moleong, 2014, hal. 248).

Penelitian ini menggunakan model analisis Milles dan Huberman. Milles dan Hubberman dalam Sugiyono mengemukakan bahwa prosedur analisis data kualitatif dilakukan dengan cara melakukan hubungan timbal-balik aktif antara peneliti dengan subjek penelitian dan berlangsung sinambung sampai tuntas, sehingga diperoleh data yang penuh (Sugiyono, 2015, hal. 246). Analisis data deskriptif dilakukan pada tahap pengumpulan data atau data collection, setelah data terkumpul langkah selanjutnya adalah mereduksi data atau data reduction, 
menampilkan data atau data display, dan mengambil kesimpulan atau conclusion drawing atau verification.

Teknik analisis yang dilakukan yaitu wawancara semi terstruktur untuk menggali informasi yang diperoleh selama melakukan wawancara. Wawancara dilakukan terhadap guru dan siswa di kelas sebagai subjek penelitian. Analisis kedua yakni analisis data hasil observasi. Semua hasil analisis ditulis dan ditampilkan dalam bentuk gambaran secara umum. Analisis juga dilakukan dengan memahami gejala yang ditemukan selama melakukan observasi di lapangan kemudian mengaitkannya dengan teori yang relevan sehingga dapat ditemukan jawaban mengapa gejala tersebut muncul, dan dapat memahami kasus yang diteliti.

\section{HASIL DAN PEMBAHASAN}

Tujuan penelitian ini adalah untuk mengetahui faktor-faktor penyebab rendahnya hasil belajar sejarah siswa Kelas V SDN Panancangan 4 Kota Serang, Banten. Teknik pengumpulan data yang digunakan dalam penelitian ini adalah observasi, wawancara, dan dokumentasi. Setelah terkumpul, data dianalisis setelah sebelumnya diseleksi, ditelaah dan direduksi agar kesimpulan yang diperoleh dapat diverifikasi dan dijadikan sebagai temuan penelitian yang berarti. Data yang dideskripsikan pada bagian ini adalah hasil observasi dan wawancara yang lakukan terhadap siswa dengan hasil belajar sejarah yang rendah di Kelas V SDN Panancangan 4 Kota Serang, Banten, guru, dan orang tua siswa yang bersangkutan. Data pendukung yang digunakan adalah observasi kegiatan pembelajaran dan dokumentasi berupa portofolio pekerjaan siswa dan perangkat pembelajaran yang digunakan oleh guru.

\section{Hasil Penelitian}

Dalam penelitian ini, dikumpulkan informasi baik berupa tes hasil belajar yang telah dilakukan oleh guru berupa pemberian soal yang sesuai dengan materi yang diajarkan maupun wawancara pada siswa yang mengalami kesulitan. Berdasarkan hasil jawaban soal tes yang diperoleh dari guru, diperoleh data tes hasil belajar. Agar gejala rendahnya hasil belajar dapat terlihat dengan jelas, data tersebut kemudian diolah dan disajikan pada Tabel 1. Informasi pada Tabel 1 menyajikan ukuran keberhasilan belajar menggunakan batasan KKM, yakni 65. Siswa dikatakan tuntas apabila mendapatkan nilai melebihi KKM dan sebaliknya, siswa dikatakan tidak tuntas apabila mendapatkan nilai kurang dari KKM. Siswa yang memperoleh nilai kurang dari KKM dikatakan sebagai siswa dengan hasil belajar yang rendah dan mengalami kesulitan. 
Tabel 1. Data hasil belajar

\begin{tabular}{lll}
\hline No & Keterangan & Nilai \\
\hline 1 & Banyaknya siswa yang tuntas & 3 \\
2 & Persentase ketuntasan & $8 \%$ \\
3 & Banyaknya siswa yang tidak tuntas & 34 \\
4 & Persentase ketidaktuntasan & $92 \%$ \\
\hline
\end{tabular}

Dari tabel di atas terlihat bahwa banyaknya siswa yang tuntas hanya 8\% dari 37 siswa. Sementara sisanya, yakni sebanyak $92 \%$ atau 34 siswa tidak tuntas atau memiliki hasil belajar yang rendah.

Untuk mendapatkan informasi lebih detil mengapa hal tersebut terjadi, dilakukan wawancara terhadap 34 siswa dengan hasil belajar yang rendah. Dari hasil wawancara diperoleh informasi bahwa hal tersebut terjadi karena ada beberapa kendala yang mereka alami, seperti kurangnya motivasi mereka dalam belajar. Mereka juga menyebutkan mengenai metode dan media yang digunakan oleh guru ketika mengajar tidak membuat mereka cepat mengerti sehingga siswa mengalami kesulitan dalam belajar, mereka tidak diajak aktif dalam kegiatan pembelajaran. Sebagai akibatnya, sebagian besar siswa tidak menguasai materi yang sampaikan oleh guru. Kedua faktor ini cukup menarik karena saling mendukung. Pertama, motivasi siswa dalam mengikuti kegiatan pembelajaran sangat rendah. Kedua, kegiatan pembelajaran cenderung membuat mereka pasif. Siswa yang tidak termotivasi berada pada suasana belajar yang pasif menjadikan kegiatan belajar tidak mencapai tujuan sesuai dengan yang diharapkan. Sebagai akibatnya, setelah dilakukan tes, hasil tes mereka rendah.

Dari sisi lain, dari wawancara yang dilakukan terhadap guru yang mengajar di kelas tersebut menyebutkan bahwa sebenarnya Mata Pelajaran IPS (dalam hal ini materi sejarah) bukan materi yang tergolong sulit (dikuasai) oleh siswa. Namun beliau menyebutkan ada beberapa siswa yang mengalami kesulitan dalam belajar. Menurutnya, hal itu disebabkan oleh kurang aktifnya siswa (tidak terlibat) ketika mengikuti kegiatan pembelajaran di kelas, tidak mau (atau malu) bertanya ketika tidak paham dengan apa yang disampaikan. Sementara faktor dari luar yang juga menurutnya turut memberikan andil terhadap fenomena ini adalah karena kurangnya dukungan sekolah terhadap penyediaan fasilitas seperti bahan ajar. Demikian juga orang tua siswa. Kebanyakan di antara orang tua, menurutnya, tidak memberikan dukungan terhadap penyediaan bahan ajar seperti buku atau LKS. Akibatnya, satu-satunya sumber yang siswa miliki hanya guru yang menyampaikan. Berdasarkan pengakuan guru (dan siswa), keadaan ini juga didukung dengan strategi atau pemilihan metode mengajar yang diterapkan oleh guru ketika menyampaikan materi dinilai kurang tepat seperti penggunaan metode yang berpusat pada guru dan tidak (atau kurang) memanfaatkan beragam media pembelajaran yang 
mendukung. Sebagai akibatnya, siswa kesulitan memahami materi yang disampaikan sehingga menyebabkan hasil belajar mereka rendah.

Informasi yang diperoleh dari guru mengenai penyediaan sumber belajar kemudian dikonfirmasi kepada orang tua melalui aktivitas wawancara. Dari hasil wawancara tersebut, diperoleh informasi bahwa mereka kurang memberikan motivasi kepada anaknya untuk belajar; kurang memberikan dukungan terhadap penyediaan sumber belajar; kurang memberikan waktu untuk menemani dan membimbing anak belajar di rumah; dan kurang peka terhadap perkembangan belajar anak. Beberapa fakta tersebut jelas akan menghambat siswa dalam belajar. Akibatnya siswa termotivasi untuk mengikuti kegiatan belajar, termasuk belajar sejarah. Akhirnya penguasaan siswa terhadap materi yang diajarkan juga rendah sehingga hasil belajar siswa juga rendah.

Berdasarkan hasil wawancara dengan ketiga subjek di atas, diperoleh informasi bahwa secara umum faktor yang menyebabkan hasil belajar sejarah yang rendah dapat diklasifikasikan ke dalam dua faktor, yakni: 1) faktor internal atau faktor yang berasal dari dalam diri siswa; dan 2) faktor eksternal atau faktor yang berasal dari luar siswa dalam hal ini guru dan orang tua siswa.

Tabel 2. Faktor-faktor yang menyebabkan rendahnya hasil belajar siswa.

\begin{tabular}{|c|c|c|c|}
\hline \multicolumn{2}{|c|}{ Faktor Internal } & \multicolumn{2}{|l|}{ Faktor Eksternal } \\
\hline 1. & Motivasi & 1. Cara guru mengajar & 1. Dukungan yang \\
\hline 2. & Sumber belajar & 2. Media dan sumber & diberikan orang tua \\
\hline 3. & Malu bertanya & yang digunakan guru & 2. Pendampingan belajar \\
\hline 4. & Kesulitan mengingat & mengajar & 3. Motivasi yang diberikan \\
\hline 5. & Psikologis seperti & 3. Motivasi yang & orang tua \\
\hline & minder, merasa tidak & diberikan guru & \\
\hline & memiliki dukungan, & & \\
\hline & merasa tidak memiliki & & \\
\hline & tujuan, kurang & & \\
\hline & perhatian dari orang & & \\
\hline & tus & & \\
\hline
\end{tabular}

Dalam kegiatan pembelajaran, guru merupakan komponen utama yang menentukan tingkat ketercapaian tujuan pembelajaran. Karena guru terlibat langsung dalam pembelajaran mulai dari perencanaan, pelaksanaan, sampai dengan penilaian hasil belajar. Berdasarkan hasil pengamatan kegiatan pembelajaran, terlihat bahwa kegiatan pembelajaran didominasi oleh penjelasan guru dalam bentuk ceramah satu arah. Guru terlihat sangat menguasai materi sehingga guru terus menjelaskan materi meskipun keadaan kelas mulai tidak kondusif. Guru 
juga tidak memanfaatkan media dan sumber belajar yang ada secara optimal. Penggunaan media pembelajaran sejarah sangat membantu untuk siswa belajar sejarah (Tanjung, 2015).

Keseluruhan kegiatan pembelajaran yang direncanakan dan dilaksanakan oleh guru dan siswa merupakan cara yang dilakukan guru untuk mencapai tujuan pembelajaran. Salah satu indikator apakah tujuan tersebut sudah tercapai atau belum adalah hasil belajar siswa. Guru dapat menentukan tingkat keberhasilan belajar menggunakan kriteria baku seperti KKM. Secara kognitif, tujuan pembelajaran dikatakan berhasil tercapai apabila sebagian besar siswa memperoleh hasil belajar di atas KKM. Nashar mengatakan bahwa salah satu faktor yang memengaruhi hasil belajar siswa adalah perencanaan dan pelaksanaan kegiatan pembelajaran yang dilakukan oleh guru (Nashar, 2015).

Di luar sekolah, orang tua memiliki peran dalam menentukan tingkat penguasaan siswa mengenai materi yang sudah dipelajarinya di sekolah. Peran orang tua dalam hal ini di antaranya adalah perhatian dalam mendampingi siswa belajar di rumah; penyediaan fasilitas penunjang belajar; perhatian terhadap perkembangan belajar; dan motivasi untuk mengikuti kegiatan pembelajaran di sekolah. Berdasarkan hasil wawancara dengan orang tua siswa, sebagain besar orang tua mengatakan bahwa mereka tidak begitu memedulikan perkembangan belajar anaknya di sekolah karena kesibukan pekerjaan mereka. Penelitian Sunariah menunjukkan bahwa orangtua siswa yang berprofesi sebagai pedagang kurang memperhatikan perkembangan belajar anaknya karena sibuk bekerja (Sunariah \& Rijal, 2017). Dengan kesibukannya itu, orang tua juga jarang mendampingi anaknya untuk belajar di rumah atau memberikan motivasi kepada siswa untuk giat belajar. Selain itu, sebagian besar pekerjaan orang tua adalah sebagai buruh kasar, petani, dan pekerja serabutan yang notabene berpenghasilan kecil berdampak pada dukungan orang tua dalam hal penyediaan fasilitas belajar seperti buku referensi dan keperluan lainnya.

\section{PEMBAHASAN}

Berdasarkan uraian di atas diperoleh informasi bahwa faktor-faktor penyebab rendahnya hasil belajar sejarah secara umum dikategorikan menjadi dua, yakni faktor yang berasal dari dalam diri siswa atau faktor internal dan faktor yang berasal dari luar diri individi atau faktor eksternal yang dapat memberikan pengaruh baik secara langsung maupun tidak langsung terhadap proses belajar dan hasil belajar siswa pada materi sejarah.

Setelah menerima pengalaman belajar beserta usaha yang dilakukan siswa ketika belajar, hasil belajar seorang siswa ternyata dipengaruhi oleh sesuatu yang ada di dalam diri mereka (internal) baik secara baik secara fisiologis maupun secara psikologis (Sari \& Zulfa, 2019). Secara fisiologis, faktor internal yang memengaruhi tinggi atau rendahnya hasil belajar siswa adalah kondisi kesehatan. Siswa dengan kondisi fisik yang sehat memiliki kemungkinan lebih tinggi untuk memperoleh hasil belajar yang tinggi dan sebaliknya. Selain kesehatan, kondisi 
fisik siswa seperti dimilikinya luka yang mengganggu dan cacat secara fisik; juga memengaruhi tinggi atau rendahnya hasil belajar siswa. Secara psikologis, salah satu faktor yang memengaruhi hasil belajar adalah minat. Siswa yang kurang berminat pada suatu mata pelajaran akan cenderung sulit berkonsentrasi pada mata pelajaran tersebut (Kurniawan \& Liana, 2017). Minat juga menjadi salah satu faktor internal yang memengaruhi persepsi siswa. Apabila siswa tidak berminat mengikuti pembelajaran akan berdampak pada sikap siswa yang kurang memperhatikan guru dalam belajar di kelas. Lebih lanjut, munculnya minat karena adanya motif tertentu. Motif merupakan keinginan yang kuat pada diri seseorang untuk melakukan aktivitas tertentu dan tujuan tertentu sedangkan motivasi merupakan sebuah dorongan, hasrat atau minat yang begitu besar di dalam diri seseorang yang ditandai dengan timbulnya perasaan dan reaksi untuk mencapai keinginan atau tujuan tertentu (Sari \& Zulfa, 2019).

Faktor eksternal yang pertama adalah cara guru mengajar. Cara mengajar merupakan kegiatan yang dilakukan guru untuk menyampaikan materi sesuai dengan tujuan pembelajaran. Peran guru dalam kegiatan pelajaran adalah sebagai perencana dan pelaksana strategi pembelajaran. Perencanaan dan pelaksanaan strategi pembelajaran yang kurang tepat akan memengaruhi tingkat penguasaan siswa yang berdampak pada hasil belajar mereka. Strategi pembelajaran yang tepat melibatkan semua unsur yang memengaruhi ketercapaian tujuan pembelajaran seperti kondisi fisik dan psikis peserta didik, ketersediaan sumber belajar, pengalaman belajar, interaksi, penilaian, dan pengukuran hasil belajar. Kondisi fisik dan psikis siswa perlu diperhatikan oleh guru ketika merencanakan kegiatan pembelajaran agar guru dapat memilih aktivitas yang tepat untuk menyampaikan materi atau pokok bahasan tertentu. Perhatian guru terhadap kondisi fisik dan psikis siswa akan menumbuhkan motivasi siswa dalam belajar karena siswa akan merasa bahwa kepentingannya dilibatkan dalam kegiatan pembelajaran. Hasil observasi aktivitas pembelajaran menunjukkan bahwa guru lebih mengutamakan tersampaikannya materi akan tetapi aktivitas belajar siswa kurang dioptimalkan. Selain itu, siswa hanya mendengarkan penjelasan guru dan cenderung pasif dalam aktivitas belajar. Hal ini mengakibatkan pembelajaran sejarah hanya terfokus pada kegiatan menghafal konsep, sehingga penguasaan dan pemahaman siswa rendah. Hal ini menyebabkan hasil belajar siswa cenderung rendah (Rosdiana \& Musadad, 2017).

Faktor keluarga dan orang tua juga berpengaruh besar pada hasil belajar siswa karena waktu yang dimiliki siswa lebih banyak dihabiskan bersama dengan orang tua atau anggota keluarga yang lain. Sebagaimana diketahui, beban mengajar guru di sekolah (biasanya) cukup banyak dan ditambah dengan tugas administratif lain yang tidak sedikit, mengakibatkan interaksi guru dengan siswa dalam rangka memberikan motivasi atau belajar tambahan sangat minim. Sementara waktu yang tersedia di sekolah juga terbatas. Sementara waktu yang dihabiskan siswa di sekolah tidak sebanyak waktu yang tersedia di luar sekolah seperti keluarga dan orang tua. Akan tetapi, orang tua tidak mempedulikan perkembangan sekolah anaknya 
dikarenakan sibuk dengan pekerjaan masing-masing. Akibatnya, keluarga dan orang tua kurang memberikan dukungan dan motivasi, serta tidak adanya bimbingan yang diberikan orang tua atau mendampingi siswa ketika mereka belajar. Orang tua yang mampu ekonominya dan berstatus sosial yang tinggi ikut membentuk sikap anak-anak untuk maju belajar menghadapi tantangan yang semakin berat di masa-masa mendatang (Soepardjo, 2013).

\section{Upaya dalam meningkatkan hasil belajar materi sejarah}

Berdasarkan uraian di atas telah ditemukenali faktor-faktor yang memengaruhi rendahnya hasil belajar materi sejarah. Dengan demikian, untuk meningkatkan hasil belajar materi sejarah dapat diupayakan dengan cara memperbaiki masing-masing faktor penyebabnya. Berikut adalah beberapa hal yang dapat dilakukan baik oleh guru, siswa, maupun orang tua sebagai upaya untuk meningkatkan hasil belajar materi sejarah.

1. Bagi siswa

Siswa mempersiapkan diri secara fisik dan mental sebelum memulai kegiatan belajar. Kesiapan fisik dan mental diharapkan dapat memperbaiki konsentrasi, minat, dan perhatian siswa dalam pembelajaran. Siswa tidak mudah mengantuk karena kehilangan konsentrasi atau suasana yang membosankan. DePorter dan Hernacki menyatakan bahwa belajar bisa sangat menyenangkan dan belajar juga harus menyenangkan (DePorter \& Hernacki, 2003, hal. 8). Demikian pula ketika guru merancang kegiatan pembelajaran yang penuh dengan aktivitas atau berpusat pada aktivitas siswa, mereka dapat mengikuti semua kegiatan dengan baik karena mereka dalam kondisi optimal untuk belajar dan beraktivitas.

Hal yang tidak kalah pentingnya yang perlu diperhatikan siswa adalah cara belajar. Semakin siswa mengetahui cara belajar yang tepat untuk dirinya, dia akan memperoleh hasil yang optimal pada setiap kali kesempatan belajar itu datang. Informasi akan masuk ke dalam otak siswa dan tidak akan terlupakan seumur hidup apabila informasi tersebut ditangkap berdasarkan gaya belajar siswa yang bersangkutan (Chatib, 2013, hal. 33). Banyak siswa yang memperoleh nilai rendah karena siswa mengalami kesulitan dalam menyerap informasi dari yang disampaikan gurunya. Hal ini disebabkan oleh gaya mengajar yang diterapkan gurunya tidak sesuai dengan gaya belajar yang mereka miliki.

\section{Bagi guru}

Sebagai pemegang kendali utama pembelajaran di kelas, guru dapat merancang dan menerapkan aktivitas pembelajaran yang sesuai dengan tujuan instruksional materi. Agar tujuan instruksional dapat dicapai dengan baik, dalam merancang dan menerapkan aktivitas pembelajaran guru dapat memerhatikan hal sebagai berikut: 
a. Mengenali gaya belajar anak

Setiap siswa memiliki gaya belajar masing-masing yang memungkinkan siswa dapat memahami informasi yang diterima dengan baik oleh siswa (Chatib, 2009, hal. 100). Upaya memahami cara belajar siswa memang bukan hal yang mudah. Para guru perlu meyakini bahwa setiap siswa adalah unik sehingga gaya belajarnya juga masing-masing berbeda dan selalu berubah. Artinya setiap guru harus mahir membuat dan merancang aktivitas pembelajaran yang disesuaikan dengan gaya belajar siswa. Apabila paradigma ini benar-benar dipahami oleh guru, mereka tidak akan dengan mudah memberikan label siswa bodoh atau siswa tidak becus (Chatib, 2013, hal. 33).

b. Memilih gaya mengajar yang sesuai dengan gaya belajar anak

Gaya mengajar dimiliki oleh guru sebagai pemberi informasi. Pada dasarnya, gaya mengajar adalah suatu cara guru untuk mempermudah siswa dalam menyerap informasi yang diberikan sehingga mudah dipahami siswa (Chatib, 2009, hal. 100).

c. Memahami bagaimana arus informasi otak

Guru harus menyadari bahwa setiap menjalankan aktivitas mengajar, mereka bekerja dengan otak para siswa. Oleh karena itu, guru perlu mengetahui aliran masuknya arus informasi ke dalam otak siswa (Lafendry, 2018, hal. 28).

d. Memilih strategi pembelajaran yang tepat

Setalah memahami dan mengenali bagaimana siswa dapat menyerap informasi secara optimal, kemudian guru perlu merancang dan menerapkan aktivitas pembelajaran yang benar selaras dengan karakteristik pokok bahasan dan siswa. Strategi tersebut tercermin dalam pemilihan sumber, metode pembelajaran, teknik evaluasi, dan instrumen pengamatan yang digunakan dalam kegiatan pembelajaran. Sumber dan teknik evaluasi berkaitan erat dengan metode pembelajaran. Guru dapat memilih berbagai macam teknik atau metode pembelajaran yang tepat sesuai dengan karakteristik materi sejarah. Beberapa di antara metode yang dapat digunakan adalah sebagai berikut:

1) Problem Based Learning dan Inquiry. Rosdiana menyebutkan bahwa siswa yang belajar mata pelajaran sejarah dengan model Problem Based Learning dan Inquiri menunjukkan hasil belajar yang lebih baik daripada hasil belajar siswa yang belajar menggunakan model konvensional (Rosdiana \& Musadad, 2017).

2) Strategi Hollywood Squares. Ditinjau dari sisi efektivitasnya, hasil penelitian Haifatunnisa menunjukkan bahwa penggunaan strategi Hollywood Squares pada pembelajarn mata pelajaran IPS memberikan pengaruh lebih efektif 
terhadap peningkatan hasil belajar siswa dibandingkan model konvensional (Haifatunnisa \& Akrom, 2017).

3) Game Based Learning atau pembelajaran berbasis permainan. Pembelajaran berbasis permainan dapat memicu minat siswa untuk mengikuti kegiatan pembelajaran. Siswa merasa tertantang untuk mengikuti kompetisi sehat dan menunjukkan kemampuan terbaiknya dalam memenangkan setiap permainan. Di sini, guru dapat merancang permainan-permainan kreatif yang mengasah kemampuan kognitif siswa melalui proses mengingat atau menerapkan jenis-jenis permainan yang sudah baik seperti Team Games Tournament. Upaya ini diharapkan mampu membangun minat belajar siswa.

e. Mengawali pembelajaran dengan menarik

Seorang guru hendaknya mampu membuat suasana yang menarik pada awal-awal pembelajaran. Setiap buru mampu membuat efek kejut terhadap siswanya pada waktu pembukaan. Antuasiasme pada awal pembelajaran akan membantu guru dalam menghidupkan suasian kelas. Cara yang dapat dilakukan antara lain dengan menggunakan metode ice breaking, permainan, video lucu, atau anekdot (Lafendry, 2019, hal. 54).

f. Memaksimalkan Apersepsi

Chatib menyebutkan bahwa menit-menit awal proses belajar di kelas adalah waktu yang sangat menentukan untuk satu jam selanjutnya (Chatib, 2013, hal. 77). Pada menit-menit awal guru perlu membangun kesadaran akan pentingnya mempelajari materi hari itu, apa saja manfaat yang akan mereka peroleh, di mana materi itu akan digunakan, atau apa saja kerugian yang akan dialami apabila siswa tidak mempelajari materi itu. Guru perlu menggugah motivasi siswa sehingga tertarik untuk mengikuti aktivitas belajar selanjutnya. Siswa yang tertarik dan termotivasi akan mengambil alih kegiatan belajar menjadi miliki mereka alih-alih sebelumnya ada di tangan guru. Aktivitas pada menit-menit awal ini disebut dengan apersepsi. Filosofi mendasar tentang teori apersepsi mengatakan bahwa manusia adalah makhluk pembelajar dalam setiap konteks perkembangan budaya tertentu. Sumber-sumber apersepsi, menurut Chatib, adalah Alpha Zone, Warmer, Pre-Teach, Scene Setting, dan Multiple Strategy (Chatib, 2013). Apersepsi merupakan jalan masuk seorang guru untuk mengantarkan siswa agar siap untuk menerima informasi dan kegiatan pembelajaran dengan secara lebih optimal. Dalam pembelajaran sejarah, guru dapat menceritakan kisah nyata yang menarik dan terkait dengan nilai-nilai sejarah yang hendak disampaikan.

g. Memilih dan menggunakan media pembelajaran yang tepat

Media pembelajaran secara umum adalah alat peraga yang digunakan oleh guru sebagai media mengajar agar materi lebih mudah disampaikan kepada siswa 
dalam proses belajar mengajar yang kemudian mampu memahami materi tersebut (Amri \& Rohman, 2013). Hasil penelitian yang dilakukan oleh Samsidar Tanjung menunjukkan bahwa hasil belajar siswa yang belajar dengan menggunakan media pembelajaran by utility (pemanfaatan lingkungan) lebih baik daripada siswa yang belajar hanya menggunakan media pembelajaran by design (buku teks) (Tanjung, 2015). Aktivitas belajar siswa dengan memanfaatkan sumber-sumber lingkungan akan memberikan pengalaman belajar yang lebih baik dibanding hanya dengan memanfaatkan buku teks saja. Fungsi media dalam pembelajaran adalah sebagai alat bantu siswa ketika belajar. Media sebagai alat bantu mempermudah siswa mempelajari atau mendapatkan informasi esensial mengenai materi yang sedang diajarkan. Media pembelajaran yang digunakan dapat meningkatkan daya tarik sehingga dapat memberikan pengaruh pada diri siswa untuk belajar. Gagne dalam Amri dan Rohman mengatakan bahwa media pembelajaran sebagai komponen sumber belajar di sekitar siswa yang dpat melatih siswa untuk belajar. Dengan demikian hubungan antara media pembelajaran dengan tujuan, materi, metode dan keadaan siswa harus menjadi perhatian dan pertimbangan guru untuk memilih dan menggunakan media dalam pembelajaran di kelas (Amri \& Rohman, 2013).

Anas dalam Masturoh menyatakan bahwa pembelajaran dengan menggunakan alat peraga dapat menumbuhkan minat belajar siswa karena pelajaran menjadi lebih menarik, memperjelas makna bahan pelajaran sehingga siswa lebih mudah memahaminya, metode mengajar akan lebih bervariasi sehingga siswa tidak akan mudah bosan, karena aktivitas belajar menjadi berpusat kepada siswa. Pokok bahasan yang sebelumnya hanya sebatas teori dan tekstual, menjadi dapat diamati, dilakukan, disimulasikan, dan didemonstrasikan oleh siswa menggunakan memanfaatkan alat peraga atau media pembelajaran lainnya (Masturoh \& Khaeroni, 2017). Guru dapat menggunakan berbagai macam media untuk menyampaikan materi seperti poster atau gambar.

h. Memotivasi siswa

Guru hendaknya lebih memahami kondisi siswa dengan memberikan motivasi kepada siswa baik dari segi internal maupun eksternal, karena dengan demikian guru akan dapat memotivasi siswa dalam belajarnya (Yana, Rohaetin, \& Oktobery, 2019).

i. Menutup kegiatan belajar dengan pesan yang tersirat dari peristiwa sejarah yang sedang dipelajari

Guru dapat menutup kegiatan belajar dengan menyimpulkan materi yang sudah disampaikan. Agar kesimpulan tersebut berkesan dan selalu tertanam dalam alam 
bawah sadar siswa, guru dapat menggunakan ungkapan atau pelajaran penting yang tersirat di dalam peristiwa yang sedang dipelajari. Ketika guru menyebutkan pelajaran penting yang terkandung dalam sebuah peristiwa, siswa dapat merekam peristiwa tersebut karena memiliki makna yang dekat dengan kehidupan seharihari. Dengan demikian, diharapkan siswa dapat mengingat materi yang telah disampaikan dan melakukan sintesis, analisis, dan evaluasi terhadap peristiwa atau kejadian yang dihadapinya sehari-hari.

Berdasarkan uraian di atas dapat ditarik kesimpulan mengenai beberapa upaya yang dapat dilakukan untuk mengatasi faktor-faktor penyebab rendahnya hasil belajar. Secara sederhana terlihat bahwa setiap subjek yang terlibat dalam aktivitas pembelajaran dapat mengambil peran untuk mengatasinya. Tidak hanya dari sisi siswa dan orang tua saja. Seorang pendidik juga berperan dalam meningkatkan hasil belajar yang didapatkan para siswa lebih tergantung pada siswa itu sendiri, namun diharapkan seorang pendidik juga bisa berperan dalam meningkatkanya.

3. Bagi orang tua

Untuk meningkatkan hasil belajar siswa pada materi sejarah, diharapkan kepada orang tua agar selalu memberikan dorongan kepada anaknya sebagai siswa untuk dapat berprestasi dengan cara memberikan fasilitas belajar sesuai dengan karakteristik minat belajarnya sehingga diharapkan siswa menjadi lebih maksimal dalam meraih prestasi belajarnya dan kesadaran sejarah yang tinggi juga dapat tercapai (Basyari, 2013). Orang tua juga diharapkan dapat mendampingi siswa ketika belajar di rumah atau mengingatkan anaknya agar mengulang dan mempelajari kembali materi yang sudah disampaikan di kelas. Tentunya semua orang tua berupaya agar anaknya mendapatkan pendidikan yang berkelanjutan, sampai tuntas setidaknya sesuai dengan aturan pemerintah.

\section{SIMPULAN}

Berdasarkan uraian di atas, diperoleh beberapa kesimpulan sebagai jawaban dari pertanyaan penelitian, yaitu: 1) Fenomena rendahnya hasil belajar siswa pada mata pelajaran sejarah terjadi di Kelas V SDN Penancangan 4 Kota Serang, yakni sebesar 92\% siswa memiliki hasil belajar yang rendah. 2) Rendahnya hasil belajar tersebut disebabkan oleh beberapa faktor dan diklasifikasikan ke dalam tiga faktor, yaitu:

a. Siswa, seperti motivasi mengikuti pembelajaran, sumber belajar yang digunakan oleh siswa, malu bertanya, kesulitan mengingat dan sisi psikologis seperti minder, merasa 
tidak memiliki dukungan, merasa tidak memiliki tujuan, kurang perhatian dari orang tua. Upaya untuk pencapaian hasil belajar sejarah yang dapat dilakukan oleh siswa yaitu mempersiapkan diri secara jasmaniah dan rohaniah, meningkatkan konsentrasi belajar siswa, meningkatkan semangat belajar siswa, belajar sesuai gaya belajar, dan belajar secara menyeluruh.

b. Guru, dalam proses kegiatan belajar-mengajar guru merupakan faktor utama yang menentukan tingkat keberhasilan siswa, namun guru juga bisa menjadi faktor yang menghambat keberhasilan belajar siswa. Pemilihan metode atau strategi pembelajaran yang tidak sesuai dengan karakteristik pokok bahasan yang akan disampaikan, interaksi antara guru dan siswa yang kurang baik, serta pengembangan belajar yang kurang tepat. Terdapat guru yang tidak mampu mengelola kelas dengan baik; guru tidak memedulikan suasana kelas sebelum masuk ke materi pembelajaran; penyediaan bahan pustaka di sekolah minim; dan pengunaan media pembelajaran yang kurang tepat. Jadi, secara umum faktor guru meliputi cara guru mengajar; media dan sumber yang digunakan guru mengajar; dan motivasi yang diberikan guru.

c. Faktor orang tua, orang tua kurang memedulikan perkembangan sekolah anaknya dikarenakan sibuk dengan pekerjaannya masing-masing. Selain itu, dukungan orang tua pada penyediaan sarana dan prasarana pembelajaran masih kurang, kurangnya dukungan dan motivasi dari keluarga, serta tidak adanya bimbingan yang diberikan orang tua ketika siswa belajar.

\section{DAFTAR PUSTAKA}

Amri, S., \& Rohman, M. (2013). Strategi dan Disain Pengembangan Sistem Pembelajaran. Jakarta: Prestasi Pustaka Karya.

Baharudin, \& Wahyuni, E. N. (2008). Teori Belajar \& Pembelajaran. Jogjakarta: Ar-Ruzz Media.

Basyari, A. (2013). Hubungan antara Minat dan Prestasi Belajar Sejarah dengan Kesadaran Sejarah Siswa MAN Yogyakarta III. UNIVERSITAS NEGERI YOGYAKARTA, PROGRAM STUDI PENDIDIKAN SEJARAH. YOGYAKARTA: FAKULTAS ILMU SOSIAL UNIVERSITAS NEGERI YOGYAKARTA. Retrieved Maret 04, 2019, from https:/ / eprints.uny.ac.id/22745/2/SKRIPSI.pdf.

Chatib, M. (2009). Sekolahnya Manusia: Sekolah Berbasis Multiple Intellegencies di Indonesia. (B. H., Ed.) Bandung: Kaifa.

Chatib, M. (2013). Gurunya Manusia: Menjadikan Semua Anak Istimewa dan Semua Anak Juara. (I. Subrata, Ed.) Bandung: Kaifa.

DePorter, B., \& Hernacki, M. (2003). Quantum Learning: membiasakan belajar nyaman dan menyenangkan (1 ed.). (M. Sari, Ed., \& A. Alwiyah, Trans.) Bandung: Kaifa. 
Haifatunnisa, H., \& Akrom, A. (2017). Pengaruh Penggunaan Strategi Hollywood Squares Dalam Meningkatkan Hasil Belajar IPS Materi Perjuangan Pada Masa Penjajahan Belanda. PRIMARY: Jurnal Keilmuan dan Kependidikan Dasar, 9(2), 225-242.

Khaeroni, K., \& Nopriyani, E. (2018). Analisis Kesulitan Belajar Siswa Kelas V SD/MI pada Pokok Bahasan Sistem Koordinat. AULADUNA: Jurnal Pendidikan Dasar Islam, 5(1), 76-93. doi:https://doi.org/10.24252/auladuna.v5i1a7.2018

Kurniawan, A., \& Liana, C. (2017). Hubungan antara Minat Belajar Sejarah dengan Prokrasinasi Akademik pad Mata Pelajaran Sejarah Siswa Kelas XI SMA Negeri 1 Ngimbang. AVATARA, e-Journal Pendidikan Sejarah, 5(1), 1599-1608. Retrieved from https://jurnalmahasiswa.unesa.ac.id/index.php/avatara/article/view/18167

Kurniawan, B., Wiharna, O., \& Permana, T. (2017). Studi Analisis Faktor-faktor yang Memengaruhi Hasil Belajar pada Mata Pelajaran Teknik Listrik Dasar Otomotif. Journal of Mechanical Engineering Education, 4(2), 156-162. doi:https://doi.org/10.17509/jmee.v4i2.9627

Lafendry, F. (2018). Great Teacher: Pencetak Anak Berkarakter. Jakarta: Gramedia.

Lafendry, F. (2019). Guru Kreatif dan Menyenangkan pada Era Milenial. Jakarta: Salemba Humanika.

Masturoh, I., \& Khaeroni, K. (2017). Pengaruh Penggunaan Alat Peraga Geoboard Terhadap Hasil Belajar Siswa Pada Pokok Bahasan Geometri. Primary : Jurnal Keilmuan Dan Kependidikan Dasar, 9(2), 189-210. doi:http:// dx.doi.org/10.32678/primary.v9i02.425

Moleong, L. J. (2014). Metodologi Penelitian Kualitatif. Bandung: PT Remaja Rosdakarya.

Nashar, N. (2015). Pengaruh Metode Pembelajaran dan Kemampuan Berpikir Kritis terhadap Hasil Belajar Sejarah Siswa. Candrasangkala, 1(1), 18-23. doi:http://dx.doi.org/10.30870/candrasangkala.v1i1.746

Rosdiana, D., \& Musadad, A. (2017). Pengaruh Penggunaan Model Pembelajaran Problem Based Learning, Inquiri dan Konvensional terhadap Prestasi Belajar Sejarah Ditinjau dari Minat Belajar Siswa. HISTORIKA, 20(1), 42-54.

Sari, D., \& Zulfa, J. (2019). Faktor-faktor Penyebab Rendahnya Hasil Belajar Sejarah di SMA. Seminar Nasional Sejarah ke 4 Jurusan Pendidikan Sejarah Universitas Negeri Padang (pp. 584-589). Padang: Jurusan Pendidikan Sejarah Universitas Negeri Padang. doi:https://doi.org/10.31227/osf.io/zb53m

Slameto. (2015). Belajar dan Faktor-Faktor yang Memengarubi. Jakarta: PT Rineka Cipta.

Soepardjo, S. (2013). Kontribusi Status Sosial Ekonomi Keluarga dan Sikap Kebangsaan terhadap Prestasi Belajar Sejarah. Jurnal Penelitian dan Evaluasi Pendidikan, 17(1), 108126. doi:https://doi.org/10.21831/pep.v17i1.1364

Sugiyono. (2015). Metode Penelitian Kuantitatif, Kualitatif dan R\&D. Bandung: Alfabeta. 
Sunariah, S., \& Rijal, M. R. (2017). Analisis Kesulitan Belajar Siswa Pada Pembelajaran Matematika Materi Pecahan. Primary : Jurnal Keilmuan Dan Kependidikan Dasar, 9(1), 93110.

Susanto, A. (2013). Teori Belajar Dan Pembelajaran Di Sekolah Dasar. Jakarta: Prenadamedia Group.

Syah, M. (2013). Psikologi Belajar. Jakarta: Raja Grafindo Persada.

Tanjung, S. (2015). Pengaruh Media Pembelajaran dan Gaya Kognitif terhadap Hasil Belajar Sejarah. Paramita: Historical Studies Journal, 25(2), 261-271. doi:https://doi.org/10.15294/paramita.v25i2.5170

Yana, Y., Rohaetin, S., \& Oktobery, R. (2019). Upaya Guru Memotivasi Belajar Siswa Dalam Pembelajaran IPS Di SMP Negeri 2 Palangka Raya. Jurnal Pendidikan Ilmu Pengetahuan Sosial (JPIPS), 11(2), 287-295. doi:https://doi.org/10.37304/jp-ips.v11i02.513 